\title{
The Effect of Cognitive-Behavioral Parenting Skills Training (CBPST) on the Behavioral Problems of Preschool Children
}

\author{
Keyvan Zahedi ${ }^{1}$, Maryam Fatehizade ${ }^{1}$, Fatemeh Bahrami ${ }^{1}$ \& Rezvanossadat Jazayeri ${ }^{1}$ \\ ${ }^{1}$ Department of Counseling, Faculty of Education and Psychology, University of Isfahan, Isfahan, Iran \\ Correspondence: Maryam Fatehizade, Department of Counseling, Faculty of Education and Psychology, \\ University of Isfahan, 8174673441, Iran. Tel: 98-313-793-2615. E-mail: m.fatehizade@edu.ui.ac.ir
}

Received: February 18, 2016

Accepted: March 7, 2016

Online Published: March 15, 2016

doi:10.5539/res.v8n2p61

URL: http://dx.doi.org/10.5539/res.v8n2p61

\begin{abstract}
This study investigated the effectiveness of parental skills training using a cognitive-behavioral method in order to reduce the behavioral problems of the preschool children. This was a quasi-experimental study with a pretest-posttest design. The statistical population of the study consisted of all parents of the preschool children in Isfahan in educational year of 2014-2015. To this end, 32 parents (64 persons) who obtained 1.5 SD higher than the reported mean in response to the behavioral problems of their children, were randomly selected and divided into two groups of 16 parents ( 32 persons) as the treatment and control groups based on the random distribution. After conducting the pre-test for both groups, the treatment group received parental skills training using a cognitive behavioral method for six sessions during one month; however, the control group received no training. Then, for both groups, post-test was implemented and follow-up study was conducted. In order to assess the behavioral problems of the children, Child Behavior Checklist (CBCL) was used. Finally, the data were analyzed using the analysis of covariance. The results showed that the mean of the treatment group was significantly reduced compared to that of the control group in terms of the behavioral problems, anxiety, depression, somatization, social problems, thought problems, attention problems, rule-breaking behaviors, aggressive behaviors, and other problems. It could be concluded that cognitive behavioral parenting skills training was an effective way to reduce the children's behavioral problems.
\end{abstract}

Keywords: cognitive-behavioral, parenting skills training, children's behavioral problems

\section{Introduction}

Although, over the recent decades, world economic situation and treatments of diseases have been improved, behavioral disorders of the children have not been decreased (Scott, 2010). Prevalence of the behavioral disorders in different societies is relatively similar (Rescorla et al., 2007). Many behavioral disorders are completely removed in the adulthood; however, some are prevalent even in the adulthood (Kessler et al., 2005). The etiology of these behavioral disorders shows the several reasons and hypotheses; however, a single hypothesis may not explain this problem (Brook et al., 2013). These hypotheses consider certain aspects of children's abnormal behaviors such as critical adolescence, substance abuse, parents' job stresses, the unavailability of the parents, parents with psychotic disorders, parental smoking, parental substance abuse, troubled families, severe maternal depression, stressful events of life, and antisocial personality disorder (Rosenzweig et al., 2008; Rutter, 1997). The results of a survey showed that attention deficit hyperactivity disorders, oppositional defiant, conduct disorders, anxiety disorders, and depressive disorders are common among the 2-5 years old children (Egger \& Angold, 2006).

Children's behavioral disorders are divided into two general categories. First category includes disorders of emotional behaviors such as crying, isolation, and anxiety that are called internalizing problems. The second category includes the problems of aggression and delinquent behavior that are called externalizing problems. These kinds of problems include violence, oppositional defiant disorder, substance abuse and membership in criminal groups (Cummings et al., 2002). Some scholars believe that internalizing and externalizing problems of the children overlap with the disturbed family processes and emotional disturbances of parents and are predictable (Grych et al., 2002). A number of studies have shown that children in conflicting families are more vulnerable to internalizing and externalizing problems. Children are influenced by anger and aggression, even when they are not directly influenced by the anger. This means that a hostile environment has devastating effects 
on children (Jenkins et al., 2005)

The interaction between parents and children depends on the parenting skills and it is a dynamic phenomenon due to the permanent adaptation (Hartup \& Laursen, 1999). Scholars of growth psychology have considered the way parenting methods affect the growth of the children's social capabilities, notably the parenting skills (Darling \& Steinberg, 1993). Parenting skills include the special methods and practices that individually or collectively affect the child's development. Parenting skills are useful in controlling the socializing the children (Baumrind, 1991). It should be emphasized that the common methods of parenting the children are included in this definition, not methods such as the child abuse (Darling, 1999).

Baumrind (1991) studied three features: 1) reception and close relationships, 2) control, and 3) giving independence. In this way, he distinguishes between the effective and non-effective methods. The interaction of these three features results in three parenting styles: authoritative, authoritarian, and permissive. Authoritative style is characterized by the reception and close relationships, adaptive control techniques and giving independence. Authoritarian style shows the low acceptance and close relationships, high compulsive control and low giving independence. Permissive style is characterized by lovely and embracing behaviors, lack of expectations, and low control over the children's behavior. These parents prefer their children make decisions independently at all ages, even when they are not able to do this (Nancy, 2011). Querido et al. (2002) showed that authoritative parenting children style has the highest predictive power in reducing the behavioral problems of the children. In order to improve the parenting knowledge of the parents, parenting skills should be trained that this may significantly affect reducing the children's behavioral and emotional disorders (Patterson et al., 1982). Parenting training focuses on improving the skills and introducing the factors related to the parenting skills (Forehand \& Long, 1988).

Cognitive behavior therapy focuses on mental training, social and adaptive skills, and their effectiveness on the quality of parent-child relationships that have been shown in a number of studies (Cohen et al., 2010). The cognitive behavior approach focuses on the troubles, beliefs, and behaviors and shows how these beliefs cause and sustain the psychological problems (Beck, 2011). Cognitive behavior training for the parents includes training the behavioral methods for parenting the children. Patterson (1982) is one of the influential figures who showed the importance of parent-child relationships. He believed that the child's behavior may be the result of the reciprocity or imposed parent-child interactions. Parents are usually trained to develop a new set of improvement dependencies and thereby learning new behaviors. Skill training, contract adopting, and learning the correct behavioral methods play a key role in training the parents (Goldenberg \& Goldenberg, 2012).

The mental health of the children and adolescents is of great importance because childhood and adolescence is one of the most influential and the most sensitive life periods. Given that parenting the children and parent-child relationship contribute to the health of the children and families, the present study aimed to investigate the effectiveness of cognitive-behavioral parenting skills training in pre-school children and their parents in order to improve the parents' skills, thereby reducing the children's behavioral problems.

\section{Methodology}

This is a quasi-experimental study with the statistical population of all pre-school children's parents in Isfahan, Iran, under the auspices of Organization of Education in the academic year of 2014-2015. At first, one of the six districts of the Isfahan Education Organization was selected using the simple random sampling and after reaching the substantive agreement of the Isfahan Education Organization and coordinating with school management in the certain districts, 24 governmental primary school and 1000 parents were selected and invited to complete the children behavior check list.

After completing the test, 32 parents (64 fathers and mothers) who obtained the standard deviation of 1.5 higher than the reported mean in response to the behavioral problems of their children, were randomly selected. This group of parents was divided into two groups of 16 parents based on the random distribution: treatment and the control groups. The parenting skills were trained for one month and the control group received no training. In order to measure children's behavioral problems, the children behavior checklist was used.

Some criteria for participating in the study included:

1) parents should live together

2) they should have at least diploma degree

3) they should be ready to cooperate and participate in the sessions

4) They should not be divorced 
5) they should not be addicted

Moreover, the lack of participating in two consecutive sessions during the training course is of the exclusion criteria.

\section{Research Tool}

\subsection{Children Behavior Check List (CBCL)}

This questionnaire was designed by Achenbach (1978) and is used to assess the behavioral problems in 6-18 years old children. It consists of 113 questions with two choices as Yes (1) and No (0). It has also three forms of which the parent form was used in the study and was completed by the parents based on the last six-month status of their children. The questionnaire is composed of two parts. The first part is related to the children's competence in social relationships and activities at school and the second part is related to their emotional-behavioral problems. In general, this questionnaire includes eight clinical scales including externalizing problems (law-breaking behavior, aggressive behavior) and internalizing problems (withdrawal/depression, somatic complaints, anxiety/depression, social problems, thought problems, attention problems) (Achenbach, 1978).

The test reliability was determined using the test-retest method after one week. Reliability was $0.93-1$ among the interviewees. This reliability was up to 0.90 for the scales of competence, adoptive functioning, and emotional behavioral symptoms in the parent form inventory (Achenbach \& Rescorla, 2001). The test validity was high. It has been confirmed in a number of previous studies (Nakamura et al., 2009).

\subsection{Training Course Content}

The training course content of the parenting children skills has been planned using the cognitive-behavioral approach and based on the cognitive-behavioral theory, literature, and interviews with the parents and the expert consulters of the child and adolescent. In order to validate this training package, the comments of five experts were used in the ultimate version that is shown in Table 1.

Table 1. Training course content

\begin{tabular}{|c|c|c|c|}
\hline session & Objective & content & Parents' assignment \\
\hline $\begin{array}{l}\text { Introductory } \\
\text { session }\end{array}$ & st & $\begin{array}{l}\text { Familiarity with the } \\
\text { objectives and rules } \\
\text { of participation in } \\
\text { the sessions; } \\
\text { introductory } \\
\text { assessment }\end{array}$ & \\
\hline Session 1 & $\begin{array}{l}\text { Familiarity with families' attitudes on } \\
\text { parenting style; considering the parental } \\
\text { resistance, identifying the incorrect parenting } \\
\text { children scripts and correcting false beliefs; } \\
\text { familiarity with the stages of preschool } \\
\text { children development and nature of this period }\end{array}$ & $\begin{array}{l}\text { Explaining the } \\
\text { incorrect parental } \\
\text { scripts }\end{array}$ & $\begin{array}{l}\text { Write a number of } \\
\text { parental strategies } \\
\text { regarding their parental } \\
\text { practices, for example: } \\
\text { I wish my parents... A } \\
\text { good parent should ... }\end{array}$ \\
\hline Session 2 & $\begin{array}{l}\text { Discussing the children's behavioral problems } \\
\text { and the way to deal with them; familiarity with } \\
\text { family rules: (sleep hours, sleeping separately, } \\
\text { etc.) and regulating these rules; the awareness } \\
\text { of the role of couple relations and cordoning } \\
\text { the parenting behaviors; clarifying the } \\
\text { development effects of the communication } \\
\text { skills in reducing the family problems }\end{array}$ & $\begin{array}{l}\text { Preschool behavior } \\
\text { problems and the } \\
\text { role of the parenting } \\
\text { skills in their } \\
\text { reduction }\end{array}$ & $\begin{array}{l}\text { Note the consequences } \\
\text { and behavioral } \\
\text { problems of the } \\
\text { children during the } \\
\text { week } \\
\text { Implement at least two } \\
\text { rules at home }\end{array}$ \\
\hline Session 3 & $\begin{array}{l}\text { Training the skill of feeling expression; love } \\
\text { skill for the children and unconditional love; } \\
\text { recognizing the way parents encounter with the } \\
\text { children emotions (fear, anger, love) }\end{array}$ & $\begin{array}{l}\text { parents' emotional } \\
\text { skills in emotional } \\
\text { self-regulation } \\
\text { development of the }\end{array}$ & $\begin{array}{l}\text { Pay attention to your } \\
\text { children's feelings at } \\
\text { least twice every day } \\
\text { and communicate with }\end{array}$ \\
\hline
\end{tabular}


Session 4

Session 5

Session 6

Final

session
The definition of parenting style and familiarity with its various forms; explaining the parenting children styles: authoritarian, permissive, authoritative

Introducing a variety of incentives (material and non-material); punishment (kinds/conditions/alternatives); reinforcing the desirable behavior-eliminating the undesirable behaviors/off behavior; -tables of reinforcement; methods of accurate observation and evaluation of the environment to identify the problem; accurate assessment of the behavior and recording the children's behavior by parents; token economy; awareness of the unintended reinforcements; functional analysis of behavior (e.g., ignoring some part of behavior); accelerating and paying attention to the children's positive behavior by the parents; providing the conditional management or giving rewards based on the child's behavior

Understanding the irrational beliefs of the children, investigating the relationship between children and their beliefs and opinions, learning that thoughts and beliefs are not two separate realities

Posttest
Parenting children style, advantages and disadvantages

Familiarity with the control practices and children behavior change; children behavior change based on behavior engineering principles

Increasing the cognitive and meta-cognitive skills of the children
Think of the items you want your children choose. Make sure you can accept their choices

Provide a list of non-material

reinforcements in order of the importance for the children; Consider the child's behavior you like to change, then implement and evaluate a design based on the change behavior principles;

interfere with one of the child's behaviors using the table of behavior change

Consider one of the child's irrational beliefs, try to change it and evaluate the results.

SPSS-22 was used for data analysis and results were reported into two descriptive and inferential forms. In order to normalize the data for parametric tests, one-sample Kolmogorov-Smirnov test was conducted. For comparing the significant differences in the treatment group compared to the control group, analysis of covariance was used.

\section{Findings}

Descriptive results, including mean and standard deviation of variables in both control and treatment groups in pretest, posttest, and follow-up test are reported in Table 2. At first, both groups of 16 parents (32 parents) were formed but one of the parents withdrew from participating in the treatment group.

Table 2. Mean and standard deviation of the variables in the control and treatment groups

\begin{tabular}{|c|c|c|c|c|c|c|c|}
\hline \multirow[t]{2}{*}{ Variable } & \multirow[t]{2}{*}{ test } & \multicolumn{3}{|c|}{ Control group } & \multicolumn{3}{|c|}{ Experimental Group } \\
\hline & & $\mathbf{N}$ & $\mathbf{M}$ & SD & $\mathbf{N}$ & $\mathbf{M}$ & SD \\
\hline \multirow[t]{3}{*}{ Anxiety } & Pre-test & 15 & 5.40 & 3.45 & 16 & 6.25 & 3.39 \\
\hline & Post-test & 15 & 5.20 & 2.73 & 16 & 4.81 & 2.25 \\
\hline & Follow up & 15 & 5.20 & 2.88 & 16 & 5.37 & 2.57 \\
\hline \multirow[t]{3}{*}{ Depression } & Pre-test & 15 & 2 & 1.19 & 16 & 2.12 & 1.58 \\
\hline & Post-test & 15 & 2.06 & 1.38 & 16 & 1.50 & 1.21 \\
\hline & Follow up & 15 & 2.13 & 1.06 & 16 & 1.62 & 1.40 \\
\hline
\end{tabular}




\begin{tabular}{llllllll}
\hline Physical complaints & Pre-test & 15 & 2.06 & 2.46 & 16 & 2.06 & 2.35 \\
& Post-test & 15 & 2.13 & 2.06 & 16 & 1.56 & 1.71 \\
Social problems & Follow up & 15 & 2.13 & 2.41 & 16 & 1.81 & 2.34 \\
& Pre-test & 15 & 4.80 & 2.07 & 16 & 5.56 & 2.78 \\
& Post-test & 15 & 4.86 & 1.59 & 16 & 4.87 & 2.36 \\
Thinking problems & Follow up & 15 & 4.86 & 1.88 & 16 & 4.81 & 2.31 \\
& Pre-test & 15 & 3 & 1.64 & 16 & 3.31 & 2.33 \\
& Post-test & 15 & 3.06 & 1.38 & 16 & 2.75 & 1.94 \\
Attention problems & Follow up & 15 & 3.06 & 1.43 & 16 & 3.12 & 2.12 \\
& Pre-test & 15 & 4.20 & 1.89 & 16 & 5.31 & 2.70 \\
& Post-test & 15 & 4.20 & 1.69 & 16 & 4.62 & 2.50 \\
rule-breaking behavior & Follow up & 15 & 4.26 & 1.48 & 16 & 4.25 & 2.17 \\
& Pre-test & 15 & 2.13 & 1.59 & 16 & 3.50 & 2.36 \\
& Post-test & 15 & 2.33 & 1.4 & 16 & 3.18 & 2.19 \\
Aggressive behavior & Follow up & 15 & 2.40 & 1.40 & 16 & 2.93 & 2.32 \\
& Pre-test & 15 & 6.86 & 2.23 & 16 & 8.18 & 4.56 \\
& Post-test & 15 & 6.73 & 2.40 & 16 & 7.25 & 4.05 \\
Other problems & Follow up & 15 & 6.66 & 2.12 & 16 & 7.06 & 3.90 \\
& Pre-test & 15 & 4.06 & 3.17 & 16 & 4.81 & 2.78 \\
& Post-test & 15 & 4.13 & 3.15 & 16 & 4 & 2.16 \\
& Follow up & 15 & 4.13 & 2.97 & 16 & 4.31 & 2.54 \\
\hline & & & & & & &
\end{tabular}

In order to normalize the data for parametric tests, one-sample Kolmogorov-Smirnov test was used. The results showed that research variables were not significant at a significance level of $p \leqslant 0.05$. Therefore, the error distribution of scores of variables is normal and parametric tests can be implemented. In addition, the results of Levine test in Table 3 shows that research groups are comparable with each other.

Table 3. Results of Levine test for analyzing the equality of group variances

\begin{tabular}{llllll}
\hline Test & Variable & F & df1 & df2 & Sig. \\
\hline Anxiety & Post-test & .008 & 1 & 29 & .928 \\
Depression & Follow up & .607 & 1 & 29 & .442 \\
Physical complaints & Post-test & 2.400 & 1 & 29 & .132 \\
& Follow up & 4.365 & 1 & 29 & .046 \\
Social problems & Post-test & .803 & 1 & 29 & .378 \\
\multirow{3}{*}{ Thinking problems } & Follow up & 2.555 & 1 & 29 & .121 \\
& Post-test & .353 & 1 & 29 & .557 \\
Attention problems & Follow up & 1.245 & 1 & 29 & .274 \\
\multirow{2}{*}{ Rule-breaking behavior } & Post-test & .948 & 1 & 29 & .338 \\
& Follow up & .669 & 1 & 29 & .420 \\
& Post-test & .312 & 1 & 29 & .581 \\
& Follow up & 2.087 & 1 & 29 & .159 \\
\hline
\end{tabular}




\begin{tabular}{llllll}
\hline Aggressive behavior & Post-test & .088 & 1 & 29 & .769 \\
& Follow up & .763 & 1 & 29 & .390 \\
Other problems & Post-test & .519 & 1 & 29 & .477 \\
& Follow up & .248 & 1 & 29 & .622 \\
\hline
\end{tabular}

Table 4. Results of multivariate covariance analysis on the post-test scores by controlling the pretests of the dependent variable

\begin{tabular}{llllllllll}
\hline Effect & & Value & $\mathrm{F}$ & $\begin{array}{l}\text { Hypothesis } \\
\mathrm{df}\end{array}$ & $\begin{array}{l}\text { Error } \\
\mathrm{df}\end{array}$ & $\begin{array}{l}\text { Sig } \\
\text { Partial Eta } \\
\text { Squared }\end{array}$ & $\begin{array}{l}\text { Noncent. } \\
\text { Parameter }\end{array}$ & $\begin{array}{l}\text { Observed } \\
\text { Power }\end{array}$ \\
\hline Intercept & $\begin{array}{l}\text { Pillai's } \\
\text { Trace }\end{array}$ & .991 & 19.10 & 18 & 3 & .016 & .991 & 343.92 & .923 \\
& $\begin{array}{l}\text { Wilks' } \\
\text { Lambda }\end{array}$ & .009 & 19.10 & 18 & 3 & .016 & .991 & 343.92 & .923 \\
& $\begin{array}{l}\text { Hotelling's } \\
\text { Trace }\end{array}$ & 114.64 & 19.10 & 18 & 3 & .016 & .991 & 343.92 & .923 \\
& $\begin{array}{l}\text { Roy's } \\
\text { Largest } \\
\text { Root }\end{array}$ & 114.64 & 19.10 & 18 & 3 & .016 & .991 & 343.92 & .923 \\
\hline group & $\begin{array}{l}\text { Pillai's } \\
\text { Trace } \\
\text { Wilks' }\end{array}$ & .991 & 17.74 & 18 & 3 & .018 & .991 & 319.40 & .906 \\
$\begin{array}{l}\text { Lambda } \\
\text { Hotelling's } \\
\text { Trace } \\
\text { Roy's } \\
\text { Largest } \\
\text { Root }\end{array}$ & 106.46 & 17.74 & 18 & 3 & .018 & .991 & 319.40 & .906 \\
\hline
\end{tabular}

As shown in Table 4, the significant levels of the test indicate that training the parenting skills based on the cognitive-behavioral approaches has reduced the mean of the behavioral problems in preschool children in the treatment group compared to the control group at least in one of the stages of the post-test and follow-up test. The results of MANCOVA show the difference (99.1\%). This shows that $99.1 \%$ of the individual differences in scores of the behavioral problems in preschool children are related to the effects of group membership. The statistical power nearly 1 shows the adequacy of sample size.

The significant levels of all components show that there is a significant difference between the control and treatment groups at least in terms of one dependent variables. For understanding the differences, the results of covariance analysis are presented in Table 5. 
Table 5. Multivariate covariance analysis of children's behavior problems

\begin{tabular}{|c|c|c|c|c|c|c|c|c|c|c|}
\hline variables & $\begin{array}{l}\text { Dependent } \\
\text { Variable }\end{array}$ & $\begin{array}{l}\text { Type } \\
\text { Sum } \\
\text { Squares }\end{array}$ & $\begin{array}{l}\text { III } \\
\text { of }\end{array}$ & $\mathrm{df}$ & $\begin{array}{l}\text { Mean } \\
\text { Square }\end{array}$ & $F$ & Sig. & $\begin{array}{l}\text { Partial Eta } \\
\text { Squared }\end{array}$ & $\begin{array}{l}\text { Noncent } \\
\text { Parameter }\end{array}$ & $\begin{array}{l}\text { Observed } \\
\text { Power }\end{array}$ \\
\hline \multirow[t]{2}{*}{ Anxiety } & Post-test & 5.86 & & 1 & 5.86 & 11.84 & .003 & .37 & 11.84 & .905 \\
\hline & Follow up & 1.04 & & 1 & 1.04 & 5.41 & .031 & .21 & 5.41 & .601 \\
\hline \multirow[t]{2}{*}{ Depression } & Post-test & 3.26 & & 1 & 3.26 & 15.37 & .001 & .43 & 15.37 & .961 \\
\hline & Follow up & 2.64 & & 1 & 2.64 & 17.32 & .000 & .46 & 17.32 & .977 \\
\hline \multirow{2}{*}{$\begin{array}{l}\text { Physical } \\
\text { complaints }\end{array}$} & Post-test & 2.13 & & 1 & 2.13 & 8.90 & .007 & .30 & 8.90 & .810 \\
\hline & Follow up & .89 & & 1 & .89 & 6.80 & .017 & .25 & 6.80 & 699 \\
\hline \multirow{2}{*}{$\begin{array}{l}\text { Social } \\
\text { problems }\end{array}$} & Post-test & 2.82 & & 1 & 2.82 & 10.67 & .004 & .34 & 10.67 & .874 \\
\hline & Follow up & 2.97 & & 1 & 2.97 & 10.09 & .005 & .33 & 10.09 & .856 \\
\hline \multirow{2}{*}{$\begin{array}{l}\text { Thinking } \\
\text { problems }\end{array}$} & Post-test & 1.71 & & 1 & 1.71 & 10.21 & .005 & .33 & 10.21 & .860 \\
\hline & Follow up & .31 & & 1 & .31 & 2.26 & .148 & .10 & 2.26 & .299 \\
\hline \multirow{2}{*}{$\begin{array}{l}\text { Attention } \\
\text { problems }\end{array}$} & Post-test & 2.34 & & 1 & 2.34 & 6.48 & .019 & .24 & 6.48 & .678 \\
\hline & Follow up & 5.00 & & 1 & 5.00 & 9.69 & .005 & .32 & 9.69 & .842 \\
\hline \multirow{2}{*}{$\begin{array}{l}\text { Law-breaking } \\
\text { behavior }\end{array}$} & Post-test & .89 & & 1 & .89 & 5.64 & .028 & .22 & 5.64 & .618 \\
\hline & Follow up & 3.24 & & 1 & 3.24 & 6.43 & .020 & .24 & 6.43 & .675 \\
\hline \multirow{2}{*}{$\begin{array}{l}\text { Aggressive } \\
\text { behavior }\end{array}$} & Post-test & 3.25 & & 1 & 3.25 & 7.90 & .011 & .28 & 7.90 & .763 \\
\hline & Follow up & 3.17 & & 1 & 3.17 & 6.52 & .019 & .24 & 6.52 & .681 \\
\hline \multirow[t]{2}{*}{ Other problems } & Post-test & 3.87 & & 1 & 3.87 & 9.47 & .006 & .32 & 9.47 & .833 \\
\hline & Follow up & 2.07 & & 1 & 2.07 & 10.00 & .005 & .33 & 10.00 & .853 \\
\hline
\end{tabular}

The results of covariance analysis on the sub-scales of the children's behavioral problems imply that parental skills training based on cognitive behavioral approaches reduce the mean of preschool children's behavioral problems in the treatment group compared to the control group in the post-test and follow-up (cited in Table 2) and this difference was statistically significant. The result of the follow-up test on the variable of thought problems is not significant (sig $=0.102$ ), but it is significant in the post-test.

\section{Discussion}

This study aimed to investigate the effectiveness of the parental skills training using the cognitive-behavioral approach on symptoms of the internalizing and externalizing problems of the pre-school children. The results showed that parenting skills training based on the cognitive-behavioral approaches reduced significantly the mean of behavioral problems of the preschool children in the treatment group compared to the control group in post-test and follow-up test. In other words, training the parenting skills help the parents to reduce their children's behavior problems. The results of the present study are consistent with those of Gimpel et al. (2002), Essau (2003), Chronis et al. (2004), Cagle (2005), and Cartwright-Hatton et al. (2005).

Previous studies have also shown that unmodified behavioral parenting skills training program-based intervention is effective in reducing the symptoms of the internalizing and externalizing problems of the pre-school children (Cartwright-Hatton et al., 2005). Barrett et al. (1996) concluded that after 12 months of the intervention program, $70.3 \%$ of the children who received cognitive-behavioral interventions, and $95.6 \%$ of the children that their families received the combined cognitive-behavioral intervention and family management training in the treatment group did not show the symptoms of anxiety disorders in the post-test compared to the control group.

Tom et al. (2013) showed that parenting styles are effective on the attitudes towards the crime, substance abuse, self-esteem, and educational performance of the children. During their research, they evaluated the effect of parenting styles on self-efficacy of the adolescents. The results indicated that authoritative parenting style is very strong and is significantly related to the self-efficacy. According to regression analysis, authoritative parenting style predicts $12.8 \%$ of self-efficacy in children. Xiong and Haung (2011) showed anti-social attitudes, 
educational failure, and lack of parental control as three variables that are significantly and with high safety factor increase the likelihood of engaging young people with behavioral problems, particularly delinquency.

Results show that family is the core of human development and parents play an important role in the family members' performances using the proper training patterns. According to cognitive-behavioral approach, the problem may be caused by wrong beliefs or lack of learning that is needed to perform a skill or solve a problem. Parenting is a complex and important skill that can be promoted by training and parents can prevent their children's problems using the effective parenting styles. Parenting skills also have profound effects on a child's personality. Parents' unhealthy parenting style cause behavioral disorders in children; healthy families create a safe environment using the efficient educational patterns and contribute to their children's development.

Some of the main limitations of the present study that are obstacles to generalizing the results of the present study include:

1) reducing the children's problems to their behavioral problems;

2) inattention to the personal characteristics of parents and children;

3) through education of parents in reducing the behavioral problems of the children regardless of the direct children training; and

4) conducting the study on a limited sample of parents in Iran.

As a result, considering these limitations in the future studies is recommended. Therefore, the generalization of the results is possible only with regard to these limitations. Consideration of the parent training in cognitive-behavioral treatment approach is the merit of the present study that has not been discussed in the previous similar studies.

\section{Conclusion}

The results of this study showed that parental skills training using the cognitive-behavioral approach significantly reduced the symptoms of the children's behavioral disorders and improvement of their parenting style. Finally, it can be concluded that using a cognitive-behavioral training, parenting skills are reinforced and a high number of children's behavioral problems may be solved using the healthy training patterns. The results of this study can be used in the individual and group (with parents) consultations.

\section{Acknowledgement}

We would like to express our gratitude towards all who helped us to complete this project.

Ethical approval: Research departments were assured about the confidentiality of the results of the questionnaires. Moreover, in the implementation of the research, all the ethical principles of the confidentiality were observed. The control group after the research received the training of the independent variable.

Conflict of interest: No conflict of interest has been reported in arbitration process by the authors.

Financial resources: This study is adopted from a doctoral thesis on consultation from the University of Isfahan and all rights are preserved.

\section{References}

Achenbach, T. M. (1978). The Child Behavior Profile: I. Boys aged 6-11. Journal of consulting and clinical psychology, 46(3), 478. http://dx.doi.org/10.1037/0022-006X.46.3.478

Achenbach, T. M., \& Rescorla, L. (2001). ASEBA school-Age forms \& profiles. Burlington: Aseba.

Barrett, P. M., Dadds, M. R., \& Rapee, R. M. (1996). Family treatment of childhood anxiety: A controlled trial. Journal of consulting and clinical psychology, 64(2), 333. http://dx.doi.org/10.1037/0022-006X.64.2.333

Baumrind, D. (1991). Parenting styles and adolescent development. The encyclopedia of adolescence, 2, 746-758.

Beck, J. S. (2011). Cognitive behavior therapy: Basics and beyond. Guilford Press.

Brook, D. W., Brook, J. S., Rosen, Z., De la Rosa, M., Montoya, I. D., \& Whiteman, M. (2014). Early risk factors for violence in Colombian adolescents. American Journal of Psychiatry, 160(8), 1470-1478. http://dx.doi.org/10.1176/appi.ajp.160.8.1470

Cagle, S. E. (2005). Emotional and behavioral problems of young children: Effective interventions in the preschool and kindergarten years. Psychology in the Schools, 42(4), 449-450. http://dx.doi.org/10.1002/pits.20070 
Cartwright-Hatton, S., McNally, D., White, C., \& Verduyn, C. (2005). Parenting skills training: An effective intervention for internalizing symptoms in younger children? Journal of Child and Adolescent Psychiatric Nursing, 18(2), 45-52. http://dx.doi.org/10.1111/j.1744-6171.2005.00014.x

Chronis, A. M., Chacko, A., Fabiano, G. A., Wymbs, B. T., \& Pelham, J. W. E. (2004). Enhancements to the behavioral parent training paradigm for families of children with ADHD: Review and future directions. $\begin{array}{lllll}\text { Clinical child and family psychology review, } & 7(1), & 1-27 .\end{array}$ http://dx.doi.org/10.1023/B:CCFP.0000020190.60808.a4

Cohen, J. A., Berliner, L., \& Mannarino, A. (2010). Trauma focused CBT for children with co-occurring trauma and behavior problems. Child Abuse \& Neglect, 34(4), 215-224. http://dx.doi.org/10.1016/j.chiabu.2009.12.003

Cummings, E. M., Davies, P. T., \& Campbell, S. B. (2002). Developmental psychopathology and family process: Theory, research, and clinical implications. Guilford Press.

Darling, N., \& Steinberg, L. (1993). Parenting style as context: An integrative model. Psychological bulletin, 113(3), 487. http://dx.doi.org/10.1037/0033-2909.113.3.487

Egger, H. L., \& Angold, A. (2006). Common emotional and behavioral disorders in preschool children: Presentation, nosology, and epidemiology. Journal of Child Psychology and Psychiatry, 47(3-4), 313-337. http://dx.doi.org/10.1111/j.1469-7610.2006.01618.x

Essau, C. A. (Ed.). (2003). Conduct and oppositional defiant disorders: Epidemiology, risk factors, and treatment. Routledge.

Forehand, R., \& Long, N. (1988). Outpatient treatment of the acting out child: Procedures, long term follow-up data, and clinical problems. Advances in Behaviour Research and Therapy, 10(3), 129-177. http://dx.doi.org/10.1016/0146-6402(88)90012-4

Gimpel, G. A., Peacock, G. G., \& Holland, M. L. (2003). Emotional and behavioral problems of young children: Effective interventions in the preschool and kindergarten years. Guilford Press.

Goldenberg, H., \& Goldenberg, I. (2012). Family therapy: An overview. Cengage Learning.

Grych, J. H., Wachsmuth-Schlaefer, T., \& Klockow, L. L. (2002). Interparental aggression and young children's representations of family relationships. Journal of family psychology, 16(3), 259. http://dx.doi.org/10.1037/t02125-000

Hartup, W. W., \& Laursen, B. (1999). Relationships as developmental contexts: Retrospective themes and contemporary issues. Relationships as developmental contexts, 30, 13-35.

Jenkins, J., Simpson, A., Dunn, J., Rasbash, J., \& O’Connor, T. G. (2005). Mutual influence of marital conflict and children's behavior problems: Shared and nonshared family risks. Child development, 76(1), 24-39. http://dx.doi.org/10.1111/j.1467-8624.2005.00827.x

Kessler, R. C., Chiu, W. T., Demler, O., \& Walters, E. E. (2005). Prevalence, severity, and comorbidity of 12-month DSM-IV disorders in the National Comorbidity Survey Replication. Archives of general psychiatry, 62(6), 617-627. http://dx.doi.org/10.1001/archpsyc.62.6.617

Nakamura, B. J., Ebesutani, C., Bernstein, A., \& Chorpita, B. F. (2009). A psychometric analysis of the child behavior checklist DSM-oriented scales. Journal of Psychopathology and Behavioral Assessment, 31(3), 178-189. http://dx.doi.org/10.1007/s10862-008-9119-8

Nancy, D. (2011). Parenting Style and Its Correlates. In Clearinghouse on Elementary and Early Childhood Education.

Patterson, G. R., Chamberlain, P., \& Reid, J. B. (1982). A comparative evaluation of a parent-training program. Behavior therapy, 13(5), 638-650. http://dx.doi.org/10.1016/S0005-7894(82)80021-X

Querido, J. G., Warner, T. D., \& Eyberg, S. M. (2002). Parenting styles and child behavior in African American families of preschool children. Journal of Clinical Child and Adolescent Psychology, 31(2), 272-277. http://dx.doi.org/10.1207/S15374424JCCP3102_12

Rescorla, L., Achenbach, T., Ivanova, M. Y., Dumenci, L., Almqvist, F., ... Bilenberg. (2007). Behavioral and emotional problems reported by parents of children ages 6 to 16 in 31 societies. Journal of Emotional and behavioral Disorders, 15(3), 130-142. http://dx.doi.org/10.1177/10634266070150030101

Rosenzweig, J. M., Brennan, E. M., Huffstutter, K., \& Bradley, J. R. (2008). Child care and employed parents of 
children with emotional or behavioral disorders. Journal of Emotional and Behavioral Disorders, 16(2), 78-89. http://dx.doi.org/10.1177/1063426607312538

Rutter, M. (1997). Child psychiatric disorder: Measures, causal mechanisms, and interventions. Archives of general psychiatry, 54(9), 785-789. http://dx.doi.org/10.1001/archpsyc.1997.01830210021002

Scott, S. (2010). National dissemination of effective parenting programmers to improve child outcomes. The British Journal of Psychiatry, 196(1), 1-3. http://dx.doi.org/10.1192/bjp.bp.109.067728

Tam, C. L., Chong, A., Kadirvelu, A., \& Khoo, Y. T. (2013). Parenting styles and self-efficacy of adolescents: Malaysian scenario. Global Journal of Human-Social Science Research, 12(14-A).

Xiong, Z. B., \& Huang, J. (2011). Predicting Hmong male and female youth's delinquent behavior: An exploratory study. Hmong Studies Journal, 12, 1-34.

\section{Copyrights}

Copyright for this article is retained by the author(s), with first publication rights granted to the journal.

This is an open-access article distributed under the terms and conditions of the Creative Commons Attribution license (http://creativecommons.org/licenses/by/3.0/). 